\title{
A FRAGILIZAÇÃo DOS ESPAÇOS PÚBLICOS A PARTIR DA UTILIZAÇÃo DE CÂMERAS DE VIGILÂNCIA NA CIDADE DE VILA VELHA (ES)
}

\section{WEAKENING PUBLIC SPACES THROUGH THE USE OF SURVEILLANCE CAMERAS IN THE CITY OF VILA VELHA, ES, BRAZIL}

\author{
lafet Leonardi Bricalli ${ }^{1}$, Cláudio Luiz Zanotelli ${ }^{1}$ \\ ${ }^{1}$ Universidade Federal do Espírito Santo (UFES), Vitória, ES, Brasil
}

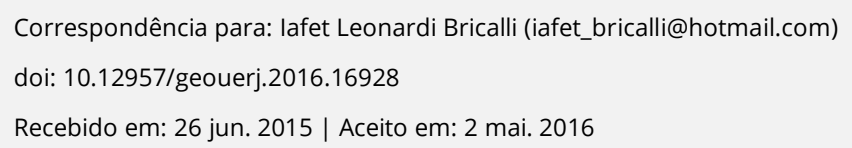

\section{RESUMO}

O artigo aborda o tema da fragilização dos espaços públicos num contexto de utilização de câmeras de vigilância, cuja problematização será feita a partir de um estudo de caso do sistema de câmeras da cidade de Vila Velha, localizada na Região Metropolitana de Vitória, Espírito Santo. Pretende-se desconstruir os discursos das administrações públicas que utilizam as câmeras sob a justificativa do "combate à criminalidade" e/ou do aumento da "sensação de segurança" proporcionada aos cidadãos, bem como demonstrar os prejuízos causados a algumas das condições que pressupõem os espaços públicos considerando as câmeras como objetos técnicos que exercem a função de controle sobre os sujeitos sociais e seus espaços. Utilizamos como metodologia a observação participante para acompanhamento do trabalho realizado no espaço onde as câmeras são operadas, bem como acompanhamos o cotidiano de três áreas monitoradas, entrevistando transeuntes, moradores e comerciantes. Os resultados indicam alguns fatores que impõem limites ao trabalho da vigilância, a aparente indiferença com que os cidadãos se relacionam com as câmeras e a fragilização dos espaços públicos, na medida em que as câmeras são potenciais e reais ameaças à liberdade, à pluralidade e à vida cotidiana dos cidadãos.

Palavras-chave: vigilância; câmeras; espaços públicos; segurança; Vila Velha.

\begin{abstract}
This article approaches the weakening of public spaces in a context of surveillance camera use, which will be discussed based on a case-study of Vila Velha surveillance camera system, a city located in the Metropolitan Area of Vitoria, Espírito Santo, Brazil. This investigation aims at deconstructing the public administration discourse, in which cameras are justifiable to "combat crime" and/or increase the "feeling of safety" among citizens. The study also aims at showing the damage caused to some of the conditions underlying the notion of public spaces if cameras are seen as technological devices that play the role of controlling social subjects and their spaces. We adopted participant observation behind the cameras to follow the work routine of camera operators and their workplace, as well as in front of the cameras to observe the everyday life in three monitored areas, interviewing passersby, residents and business owners. The results show some factors that limit the surveillance operation; the apparent indifference in which citizens relate to the cameras; and the weakening of public spaces, since cameras pose serious threats to liberty, plurality, and routine of citizens.
\end{abstract}

Keywords: Surveillance; cameras; public spaces; safety; Vila Velha. 


\section{INTRODUÇÃO}

O presente trabalho ${ }^{1}$ aborda o tema da fragilização dos espaços públicos num contexto de utilização de câmeras para fins de vigilância e controle. Para tanto, realizamos um estudo do sistema de vigilância através das câmeras presentes nos espaços públicos da cidade de Vila Velha, localizada na Região Metropolitana de Vitória, no Estado do Espírito Santo (Figura 1).

Partimos da hipótese segundo a qual vivemos em meio a objetos técnicos que ininterruptamente produzem informações sobre os sujeitos sociais e os seus espaços. Para tanto, eles exercem um tipo de vigilância cuja origem é a pretendida busca de uma "transparência total" que remonta às ideias iluministas europeias do século XVIII (FOUCAULT, 2008). A atualização dessa vigilância por esses objetos técnicos contribui para moldar um tipo de sociedade denominada por Deleuze (2007) de sociedade do controle.

Se esses objetos estão presentes em qualquer parte do planeta, nas cidades eles aparecem com maior destaque. Num contexto de "complexificação" das cidades, abre-se espaço para que elas sejam organizadas em torno da gestão de riscos que essa "complexificação" engendra. Ocorre que como resultado dessa gestão, muitas delas lançam mão de técnicas cada vez mais sofisticadas, algumas delas prisionais e/ou militares, levando alguns autores a considerá-las um arquipélago carcerário (SOJA, 2008), cidades sob controle: o novo urbanismo militar (GRAHAM, 2011) e uma fobópole (SOUZA, 2008). As câmeras de vigilância representam o exemplo mais conhecido desses objetos técnicos e são, portanto, parte essencial dos espaços urbanos controlados.

Porém, questionando o determinismo tecnológico, pretendemos demonstrar que a vigilância através de câmeras possui importantes limites considerando o trabalho humano realizado no espaço onde elas são operadas. No entanto, por meio dessa crítica não se busca construir pela negação uma espécie de legitimação de uma suposta busca de "eficácia" no combate aparente aos delitos. A intenção é

\footnotetext{
${ }^{1}$ Esse texto é produto da Dissertação de Mestrado do autor sob a orientação do co-autor no Programa de Pós-Graduação da Universidade Federal do Espírito Santo.
} 
demonstrar a irresponsabilidade política presente no discurso daqueles que justificam e promovem a utilização de câmeras para fins de segurança.

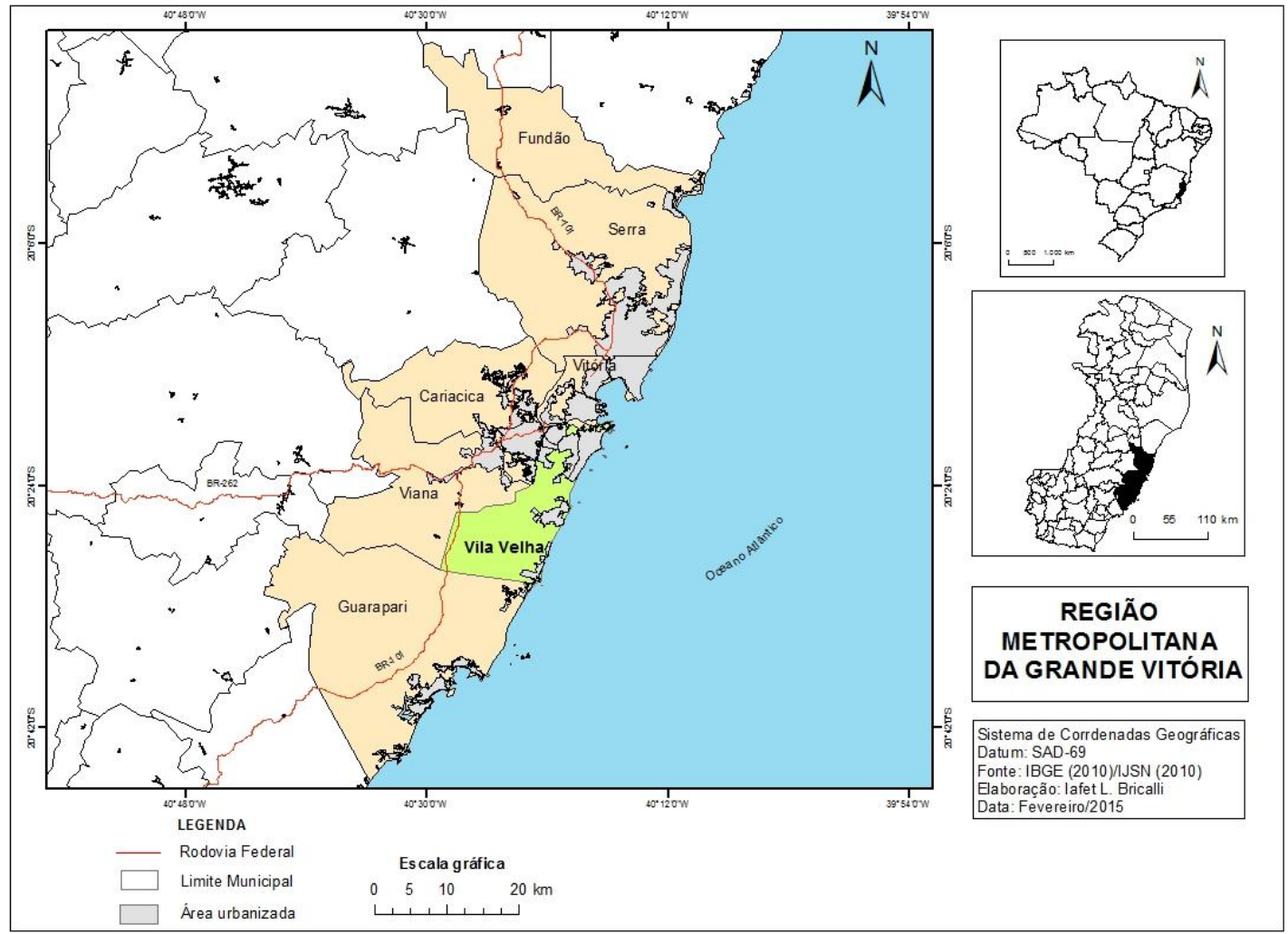

Figura 1. Localização da Região Metropolitana de Vitória com destaque para o município de Vila Velha. Fonte: IBGE (2010)/IJSN (2010).

Verificando a relação que a vigilância estabelece com os sujeitos sociais e seus espaços, pretende-se demonstrar que tampouco as câmeras oferecem a pretendida "sensação de segurança" para a população. Ao contrário, acredita-se que elas podem ser consideradas como mais um obstáculo na constituição de espaços comuns. Representando potenciais limites à pluralidade e liberdade, bem como desrespeitando acintosamente a vida cotidiana dos sujeitos, as câmeras produzem o efeito exatamente inverso quando, supostamente oferecendo segurança, acabam por aumentar o controle sobre os espaços públicos.

\section{METODOLOGIA}

Consideramos a vigilância através de câmeras uma maneira de se exercer o poder, seja contribuindo para a interiorização da vigilância pelos sujeitos sociais e alimentando um estado de controle 
permanente a partir de olhares que se multiplicam, seja registrando ininterruptamente informações sobre os sujeitos e os seus espaços. Neste sentido, nossa referência teórica principal foi Foucault (2009). A vigilância exercida pelas câmeras, por outro lado, fragiliza os espaços públicos na medida em que impõem limites às condições que o pressupõem. Para a discussão sobre a fragilização dos espaços públicos num contexto de utilização de câmeras utilizamos como referência o trabalho de Souza (2008). A fim de estabelecer comparações com outros trabalhos, utilizamos ainda como referência outros estudos de caso sobre a temática da vigilância, realizados no Brasil e no exterior. Destacam-se Firmino e Trevisan (2012), Oliva (2013), Smith (2004) e Martinais e Bétin (2004).

O nosso estudo empírico consistiu na observação do trabalho realizado na sala de controle das câmeras da cidade de Vila Velha. Realizamos uma pesquisa etnográfica curta no mês de outubro de 2014, quando passamos quatro semanas ininterruptas observando o trabalho "por detrás" das câmeras, totalizando cento e doze horas de observação. Procuramos alternar dias e horários de modo a estabelecer comparações entre eles, o que nos permitiu, ao mesmo tempo, conhecer todas as equipes que se revezam no trabalho de vigilância.

Feito o trabalho "por detrás" das câmeras, resolvemos pesquisar o que acontece "na frente" delas. Durante os meses de outubro e novembro de 2014 fizemos um trabalho de observação de três áreas da cidade de Vila Velha vigiadas por câmeras, que apresentam características socioespaciais bastante contrastantes: uma delas na Praia da Costa, o bairro de residência das pessoas de maior poder aquisitivo do município; outra na Glória, um bairro fundamentalmente comercial e industrial de fluxo intenso de pessoas, automóveis e mercadorias; e outra em Riviera da Barra, um bairro popular, periférico e com inúmeros problemas socioespaciais. Como os bairros Praia da Costa e Glória possuíam mais de uma câmera, fizemos a escolha das áreas mais movimentadas e que apresentavam a maior diversificação de usos, seja residencial, comercial, de serviço e de lazer. Para a escolha, nestes casos, baseamos-nos inicialmente na observação que fizemos na sala de controle e posteriormente na visita que fizemos aos bairros. Alternando dias e horários, procuramos descobrir as relações que aqueles espaços possuíam com a vigilância das câmeras, fazendo observações dos usos que se faziam deles e, principalmente, entrevistando moradores, transeuntes e comerciantes. 
As pesquisas realizadas na sala de controle das câmeras e nos espaços públicos por elas vigiados se complementam. O questionamento do determinismo tecnológico ocorreu tanto em relação ao trabalho daqueles que operam as câmeras quanto na relação que os sujeitos sociais estabelecem com a vigilância. Por outro lado, a função de controle das câmeras também pode ser admitida tanto quando consideramos a política de vigilância da prefeitura bem como quando verificamos as demandas dos cidadãos em relação às câmeras.

\section{A implantação do sistema de câmeras de vigilância em Vila Velha}

A cidade de Vila Velha era, em 2010, a mais populosa do Estado do Espírito Santo, com 414.586 habitantes. Ocupa uma área de $210,67 \mathrm{Km}^{2}$, sua densidade populacional é de 1.973,79 habitantes por $\mathrm{Km}^{2}$ e sua taxa de urbanização é de 99,5\%, embora 35,4\% da área total do município seja considerada área rural. Apresenta o terceiro maior Produto Interno Bruto (PIB) do Estado do Espírito Santo, atrás apenas da cidade de Serra e da capital Vitória. Em 2012, seu PIB foi de R $\$ 7,5$ bilhões, sendo que 0 setor de serviços é o mais importante do município, correspondendo a 78,62\% das riquezas produzidas, seguido da indústria $(21,18 \%)$ e da agropecuária (menos de 1\%). Relativamente rica economicamente, Vila Velha é uma cidade extremamente desigual quanto à concentração dessa riqueza (seu índice de GINI em 2003 era de 0,48) e apresenta fortes marcas de segregação socioespacial (IBGE, 2010).

As câmeras são publicamente difundidas como ferramentas que supostamente aumentam a sensação de segurança na medida em que auxiliariam o trabalho da polícia no "combate contra a criminalidade". Segundo dados disponíveis em Waiselfisz (2015), a segunda maior taxa bruta de mortalidade por arma de fogo a cada 100.000 habitantes do Brasil no ano de 2012 era do Espírito Santo (38,3), atrás somente do Estado de Alagoas (55,0). Neste mesmo ano, ainda de acordo com este critério, a taxa do 
município de Vila Velha $(44,0)$ é superior à média do Espírito Santo e superior a outras cidades brasileiras como Rio de Janeiro e São Paulo, cujas taxas foram respectivamente de 16,7 e 12,6².

Em relação aos homicídios em Vila Velha, as taxas corrigidas ${ }^{3}$ deste indicador mais do que triplicaram em 25 anos, passando de 1,5 homicídios a cada 10.000 habitantes no ano de 1980 para 5,42 em 2005, estando entre as maiores dentre as cidades do Espírito Santo (Tabela 1).

\begin{tabular}{ccccccc}
\hline Município & $\mathbf{1 9 8 0}$ & $\mathbf{1 9 8 5}$ & $\mathbf{1 9 9 0}$ & $\mathbf{1 9 9 5}$ & $\mathbf{2 0 0 0}$ & $\mathbf{2 0 0 5}$ \\
\hline Cariacica & 1,52 & 1,92 & 4,77 & 6,35 & 7,01 & 9,29 \\
Fundão & 1,40 & 1,61 & 4,62 & 4,69 & 6,10 & 7,05 \\
Jaguaré & 0,00 & 1,80 & 5,06 & 2,46 & 2,91 & 8,09 \\
Linhares & 2,70 & 2,34 & 5,13 & 2,37 & 3,70 & 8,03 \\
Santa & 1,59 & 1,71 & 4,28 & 5,29 & 5,80 & 5,35 \\
Leopoldina & & & & & & \\
Serra & 1,52 & 2,16 & 5,29 & 6,18 & 9,47 & 9,01 \\
Sooretama & 0,00 & 0,00 & 0,00 & 0,00 & 2,47 & 6,13 \\
Viana & 1,41 & 2,20 & 4,01 & 5,40 & 6,81 & 9,55 \\
Vila Velha & $\mathbf{1 , 5 0}$ & $\mathbf{1 , 9 4}$ & $\mathbf{4 , 5 7}$ & $\mathbf{6 , 7 6}$ & $\mathbf{6 , 1 5}$ & $\mathbf{5 , 4 2}$ \\
Vitória & 1,55 & 3,66 & 5,26 & 8,66 & 7,81 & 6,36 \\
\hline
\end{tabular}

Tabela 1. Evolução das taxas corrigidas de homicídios a cada 10.000 habitantes dos dez municípios do Espírito Santo que apresentavam as taxas mais elevadas no ano de 2005. Fonte: Zanotelli et. al. (2011)

Em relação aos crimes contra o patrimônio, Vila Velha compõe o conjunto de municípios do Estado do Espírito Santo que se destacam em relação a estes tipos de crimes, que se situam, em geral, nas áreas onde se concentram as riquezas, ou seja, na Região Metropolitana de Vitória e em alguns municípios importantes e costeiros do interior do Estado (Tabela 2).

\footnotetext{
${ }^{2}$ Estamos considerando as taxas brutas e estas disparidades podem ser exageradas, mas isso não impede que consideremos a importância das taxas de homicídios de Vila Velha relativamente a outras importantes cidades brasileiras, como Rio de Janeiro e São Paulo.

${ }^{3}$ As taxas corrigidas permitem contornar, em parte, os problemas de grande flutuação dos dados de criminalidade em determinado intervalo de tempo, quando se comparam unidades territoriais com populações muito díspares, o que ocorre quando se consideram apenas as taxas brutas. Neste caso, taxas de crimes em populações pequenas podem levar a interpretações apressadas que não correspondem à "realidade". Os dados das taxas corrigidas de homicídios estão disponíveis em Zanotelli et. al. (2011).
} 
No período compreendido entre os anos de 1998 e 2005, as taxas de crimes contra o patrimônio por 10.000 habitantes em Vila Velha são sempre superiores à média do Espírito Santo. As taxas oscilam no período: há uma queda em 1999 em relação ao ano anterior, mas em seguida cresce anualmente até 2003, quando volta a cair.

\begin{tabular}{ccccccccc}
\hline Município & $\mathbf{1 9 9 8}$ & $\mathbf{1 9 9 9}$ & $\mathbf{2 0 0 0}$ & $\mathbf{2 0 0 1}$ & $\mathbf{2 0 0 2}$ & $\mathbf{2 0 0 3}$ & $\mathbf{2 0 0 4}$ & $\mathbf{2 0 0 5}$ \\
\hline Anchieta & 36,50 & 62,51 & 80,23 & 118,46 & 115,11 & 145,97 & 123,48 & 74,17 \\
Colatina & 69,60 & 59,24 & 61,73 & 75,50 & 81,87 & 103,13 & 157,23 & 79,28 \\
Conceição & & & & & & & & \\
da Barra & 124,49 & 162,77 & 142,32 & 169,10 & 223,69 & 257,91 & 247,02 & 133,13 \\
Iúna & 48,26 & 40,62 & 60,44 & 84,19 & 77,03 & 102,19 & 111,80 & 77,14 \\
Jaguaré & 78,67 & 69,83 & 83,91 & 100,72 & 125,74 & 182,73 & 212,54 & 102,22 \\
Linhares & 109,00 & 131,27 & 134,50 & 130,78 & 137,64 & 147,39 & 144,60 & 83,47 \\
Marataízes & 167,26 & 141,29 & 155,90 & 151,64 & 174,12 & 151,46 & 171,12 & 78,91 \\
Piúma & 94,74 & 134,31 & 145,27 & 168,25 & 188,89 & 202,10 & 178,13 & 103,17 \\
Sooretama & 92,16 & 114,68 & 139,10 & 101,76 & 140,20 & 199,53 & 113,60 & 92,02 \\
Vila & & & & & & & & \\
Velha & $\mathbf{1 1 5 , 9 5}$ & $\mathbf{9 1 , 7 0}$ & $\mathbf{1 0 5 , 2 9}$ & $\mathbf{1 3 0 , 7 3}$ & $\mathbf{1 4 6 , 0 9}$ & $\mathbf{1 5 5 , 5 5}$ & $\mathbf{1 2 7 , 2 5}$ & $\mathbf{6 8 , 3 8}$ \\
Vitória & 152,69 & 121,16 & 120,31 & 137,83 & $\mathbf{1 5 4 , 4 3}$ & 174,99 & 184,82 & 97,43
\end{tabular}

Tabela 2. Evolução das taxas corrigidas de crimes contra o patrimônio a cada 10.000 habitantes nos onze municípios do Espírito Santo que apresentavam as taxas mais elevadas no ano de 2005. Fonte: Zanotelli et. al. (2011).

Além dos delitos e crimes que, em geral, crescem, devemos considerar os discursos dos veículos de comunicação sobre a violência e os crimes como um fator fundamental para se entender os sentimentos subjetivos de medo e insegurança que se generalizam pelas cidades e que passam a justificar uma vigilância cada vez mais permanente, contribuindo para legitimar os usos das câmeras.

O trabalho de Zanotelli e Medina (2008) analisa esses discursos nos três principais jornais impressos de circulação no Espírito Santo e revela o seu papel como intensificadores da percepção social da insegurança na Região Metropolitana de Vitória. Destacam-se, por exemplo, o aspecto de 
espetacularização das reportagens sobre crimes e violência; o tratamento desigual a quem pratica os crimes e às vítimas dependendo da posição social que ocupam como classes dominantes ou classes dominadas; e as denúncias esvaziadas em relação à incompetência do Estado (particularmente da polícia) em lidar com o tema da segurança, que acaba por desacreditar as instituições públicas, abrindo-se, assim, por exemplo, um nicho lucrativo para a atuação do mercado de segurança privada, respaldando estratégias de repressão que alimentam a cultura autoritária da polícia brasileira e admitindo práticas de justiça com as próprias mãos, marca histórica da sociedade brasileira na ausência de mediação do Estado.

Como resposta aos crimes e aos discursos públicos dominantes, as câmeras de vigilância são implantadas para demonstrar que algo está sendo feito em relação à segurança. As passagens abaixo fazem exatamente essa associação.

As câmeras servem para aumentar a sensação de segurança, elas têm o apoio da polícia militar, da polícia civil, de outros órgãos também, e elas trazem uma maior sensação de segurança. Querendo ou não, é a força policial que está presente naquele local, não está um policial militar, mas tem as câmeras, a gente tem uma certa tranquilidade, uma certa segurança. 0 mundo está muito violento, o índice de criminalidade tem aumentado, então as pessoas estão desesperadas por segurança (Entrevista com C., gestor do videomonitoramento de Vila Velha, 22/05/2014).

As câmeras estão ajudando a diminuir os índices de criminalidade do município e contribuído para potencializar a sensação de segurança dos cidadãos (Fala da secretária de Prevenção, Combate à Violência e Trânsito do município de Vila Velha presente na matéria “Videomonitoramento ajuda na prisão de suspeitos no bairro 1ํ de Maio". Acesso em: 01 abr. $2015)$.

Utilizando câmeras enquanto ferramentas para garantir "segurança", a cidade de Vila Velha estaria em sintonia com as cidades contemporâneas. Desde 2009, foram implantadas cento e dezesseis câmeras, o maior número dentre todas as cidades do Espírito Santo. A localização delas privilegia as áreas mais ricas da cidade, onde geralmente estão situadas em importantes avenidas. A seguir, 
apresentaremos os resultados de nosso trabalho "por detrás" das câmeras, particularmente aqueles relacionados aos limites da vigilância e que desmontam os discursos daqueles que as utilizam.

\section{Os limites da vigilância: "por detrás" das câmeras}

As câmeras são monitoradas em uma sala localizada no centro da cidade de Vila Velha. As imagens por elas produzidas são projetadas em monitores distribuídos nas paredes da sala e nas várias bancadas distribuídas ao redor delas. Os monitores estão distribuídos organizadamente de modo que eles formem onze conjuntos, chamados de estações. Cada estação projeta as imagens de seis a treze câmeras, dependendo da estação.

O trabalho na sala de monitoramento é realizado pelos operadores das câmeras e pelos seus supervisores, que formam seis equipes que se revezam para que a vigilância ocorra $24 \mathrm{~h}$ por dia. São três turnos de trabalho: um deles vai das $7 \mathrm{~h}$ às $15 \mathrm{~h}$, outro das $15 \mathrm{~h}$ às $23 \mathrm{~h}$, e finalmente o terceiro que vai das $23 \mathrm{~h}$ às $7 \mathrm{~h}$ do dia seguinte. Como os funcionários trabalham em regime de escala 2x2 (dois dias de trabalho e dois dias de folga), existem duas equipes de trabalho para cada turno. O número de operadores de cada equipe varia de onze a catorze e o de supervisores de dois a três, dependendo da equipe. Os operadores são distribuídos pelas onze estações da sala, sendo que cada um é responsável por uma delas. Cada estação possui várias câmeras, na prática, isso significa que cada operador tem que monitorar um conjunto de imagens ao mesmo tempo.

Nas equipes que contam com mais de onze operadores, os que "sobram" constituem a "equipe de apoio", cujo papel é auxiliar o trabalho dos que estão monitorando, seja sentando ao lado deles ou substituindo-os caso haja necessidade. O trabalho do operador consiste em visualizar as imagens projetadas pelas câmeras e também em monitorá-las. 0 monitoramento consiste em escolher uma das câmeras e, com o auxílio do mouse, apertar o botão de pausa para que a câmera "trave". Com a câmera "travada" e utilizando a ferramenta de zoom é possível escolher o lugar que se deseja "ir", num raio de aproximadamente trezentos metros. As câmeras que não estão sendo monitoradas possuem um giro automático de $360^{\circ}$ (o pré-set) que possui em média oito tomadas diferentes cuja duração é de 
aproximadamente cinco segundos cada. Já o trabalho do supervisor consiste em acompanhar o trabalho dos operadores, orientando o que deve ou não ser feito, assim como fazer a intermediação entre os operadores e a polícia, cuja comunicação é feita via rádio.

Alguns fatores relacionados ao trabalho "por detrás" das câmeras e ao tratamento dispensado ao sistema de monitoramento pela atual administração do município demonstram os limites à vigilância. 0 primeiro deles é que em várias ocasiões as câmeras não são monitoradas. Por duas razões principais. A primeira delas porque a quantidade de imagens projetadas em cada estação não é a ideal (seis a treze câmeras). Se o operador só consegue monitorar uma câmera por vez, isso significa que enquanto isso todas as outras câmeras estão funcionando em seu giro automático, cuja visualização é tanto mais difícil quanto maior for o número de câmeras. A mesma situação foi observada por Firmino e Trevisan (2012), para o caso da cidade de Curitiba, embora lá o número máximo de câmeras para cada operador não passasse de nove.

A segunda razão é que nos horários de intervalo para café e almoço muitas vezes os operadores não são substituídos. Nesses casos, as estações podem ficar vazias por até uma hora e, portanto, as câmeras não são monitoradas. Essa é uma situação comum a outros trabalhos realizados em salas de controle (SMITH, 2004; OLIVA, 2013), embora nestes estudos, os autores sugiram que os intervalos constituam estratégias informais dos operadores (sair para fumar, ler jornais e fazer palavras cruzadas, por exemplo) para ajudar a passar o tempo de trabalho, o que não é o caso do sistema de Vila Velha.

Os baixos salários dos operadores e as condições de trabalho são os principais limites à efetividade da vigilância. Foram as principais reclamações constatadas durante o trabalho na central de vigilância. Os operadores recebem $R \$ 1.110,00$ mensais brutos para um regime de trabalho de $40 \mathrm{~h}$ semanais, o que equivale a $\mathrm{R} \$ 6,87$ por hora trabalhada. Se os salários são ruins, os operadores não se esforçam minimamente para desempenhar bem suas funções, exercem um trabalho extremamente burocrático e resistem informalmente ao sistema, o que também foi verificado por Smith (2004). 
De acordo com a legislação brasileira (BRASIL, 2013), os operadores deveriam receber $30 \%$ de adicional sobre o salário relativo à periculosidade do trabalho, mas a legislação não é cumprida. Não bastassem os baixos salários, os trabalhos dos operadores são temporários. Eles são admitidos para exercerem suas funções a partir de um processo seletivo que determina um contrato de trabalho de um ano, renovável por mais um, ao mesmo tempo em que autoriza que sejam demitidos a qualquer momento. Assim, os trabalhos dos operadores são marcados pela instabilidade, o que os leva a estarem constantemente preocupados em perderem seus empregos.

A ausência de manutenção dos equipamentos é um fator importante para explicar os limites da vigilância pretendida. $\mathrm{O}$ contrato com a empresa que prestava os serviços de manutenção não foi renovado quando a nova administração assumiu a prefeitura de Vila Velha, a partir de 2013. Com isso, quarenta e três câmeras não estão funcionando (37\% do total!); algumas câmeras não gravam; alguns mouses, joysticks, monitores e computadores não funcionam; muitas câmeras estão sujas, um problema aparentemente banal que comprometia sobremaneira a visualização das imagens, já que em alguns casos é praticamente impossível ver algo.

Os problemas relativos à ausência de manutenção das câmeras parecem particulares do caso do município de Vila Velha. Embora o estudo de Oliva (2013) mencione o problema da manutenção como determinante para a eficácia da vigilância, este está restrito às câmeras quebradas. No trabalho de Firmino e Trevisan (2012), embora os autores citem os defeitos de alguns equipamentos, os serviços de manutenção são prestados. Já em estudos em outros países, como o de Smith (2004), essa situação não foi sequer mencionada.

Situações de "anormalidade" são raras nas áreas vigiadas pelas câmeras. O resultado é que os operadores passam a maior parte do tempo visualizando imagens rotineiras que tornam o trabalho monótono e repetitivo. É o que Smith (2004) denomina de boredom factor, ou seja, as longas horas de observação das imagens em que nada de "anormal" acontece. A mesma situação foi observada por Oliva (2013) e Firmino e Trevisan (2012). O tédio relacionado à observação das imagens parece, portanto, uma situação comum às salas de controle. Como resposta, aqueles que operam as câmeras 
encontram estratégias informais de monitoramento que ajudam a fazer o tempo passar: atenção dada às mulheres, aos carros e a vitrine de lojas, por exemplo. Mas, principalmente, a visualização de ocorrências (como são chamados os registros de "anormalidades" diversas) anteriormente feitas. Portanto, se a monotonia do trabalho pode, inicialmente, explicar as estratégias informais para fazer o tempo passar, estas, por outro lado, impõem mais um limite à vigilância, na medida em que enquanto isso ocorre, as câmeras não estão sendo monitoradas para os seus fins imaginados.

As informalidades que marcam o trabalho dos operadores foram interpretadas por Smith (2004) não apenas como resposta a monotonia do trabalho de operação das câmeras, mas também como resistências às condições de trabalho oferecidas. Em geral, os operadores tratam o monitoramento como uma piada e zombam daqueles que ainda minimamente se esforçam durante o trabalho. Suas posturas e conversas não deixavam dúvidas quanto a certa resistência informal ao sistema: largavam o mouse, deixavam de monitorar as telas dos postos de controle, contavam casos de suas vidas particulares em relação a bebidas, mulheres e festas, ao mesmo tempo em que conversavam sobre esses assuntos entre si. Por outro lado, estavam sempre especulando sobre outras oportunidades de empregos, sobre cursos que pretendiam fazer, enquanto aguardavam ansiosamente o fim do turno de trabalho.

As resistências ao sistema podem ser encontradas nos próprios conflitos dos operadores com os seus superiores, caso dos supervisores e do gerente, embora, em geral, houvesse mais cooperação e solidariedade entre eles, pois todos têm condições de trabalho semelhantes. Mas também ocorrem alguns desentendimentos. Os operadores não gostam que sejam cobrados em relação à sua postura e produtividade ou quanto ao rigor em relação aos horários de intervalo. Por outro lado, alguns supervisores ficam profundamente insatisfeitos com o registro de algumas ocorrências que, segundo eles, não precisam ser feitas. Esta parece uma forma encontrada pelos operadores para "zombar" do sistema, neste caso representado pela figura do supervisor. Mas esses desentendimentos não resultam em conflitos diretos, eram apenas situações de descontentamento de ambos os lados que presenciávamos. 
Se as relações entre operadores, supervisores e gerente são mais de solidariedade do que de conflito, o contrário parece ocorrer em relação à polícia militar. Como já dito anteriormente, há uma comunicação direta via rádio entre a sala de controle e a polícia da cidade de Vila Velha. Os operadores são orientados pela polícia a acompanharem alguns problemas da cidade (um semáforo que não funciona, um veículo estacionado irregularmente, animais de grande porte nas vias) e comunicarem ao órgão responsável ou a acompanharem alguma pessoa "suspeita", ao mesmo tempo em que procuram acompanhar as ocorrências policiais ouvidas pelo rádio mesmo que não tenham sido solicitados para isso. Porém, com todos os limites da vigilância que apresentamos, raramente, pra não dizer nunca, as câmeras cumprem a função de servir de auxílio à polícia ou são capazes de acompanhar as ocorrências policiais.

No período em que se permaneceu na sala de controle, em nenhum momento, por exemplo, as câmeras serviram de apoio para os casos em que era preciso entrar em contato com outro setor da prefeitura, com exceção feita às questões referentes ao tráfego. Por outro lado, e talvez ainda mais impressionante, em nenhuma ocasião os operadores conseguiram acompanhar as ocorrências transmitidas via rádio (e elas eram muitas!) em que a polícia estava envolvida. Neste caso, era interessante o contraste entre as ocorrências policiais (homicídios, violências, assaltos, etc.) e as ocorrências das câmeras (pequenas colisões, utilização de drogas, pessoas embriagadas, etc.). Já nos casos em que a polícia solicitava o apoio das câmeras, o que era comum, em apenas uma ocasião as imagens serviram de apoio, no caso para o acompanhamento de um "suspeito". As câmeras, portanto, não possuem nenhuma credibilidade com a polícia.

\section{As relações das câmeras com os espaços vigiados}

Apresentados os limites da vigilância "por detrás" das câmeras, mostraremos como a vigilância se relaciona com os entrevistados e os seus espaços nas três áreas de estudo que elegemos para a pesquisa. 
A área da Praia da Costa escolhida para a pesquisa (Figura 2) apresenta prédios residenciais, atividades comerciais formais e informais, uma importante avenida, um largo calçadão, uma ciclovia, áreas de lazer, uma vila de pescadores e, claro, a praia. Trata-se de um bairro onde moram as categorias sociais "médias" (médicos, engenheiros, professores, pequenos comerciantes etc.) e aquelas representando os setores do que consideramos como classes dominantes (dirigentes de empresas, patrões em geral). A circulação de pessoas e automóveis é intensa, particularmente nos finais de semana e no período do verão brasileiro, entre os meses de dezembro e março.

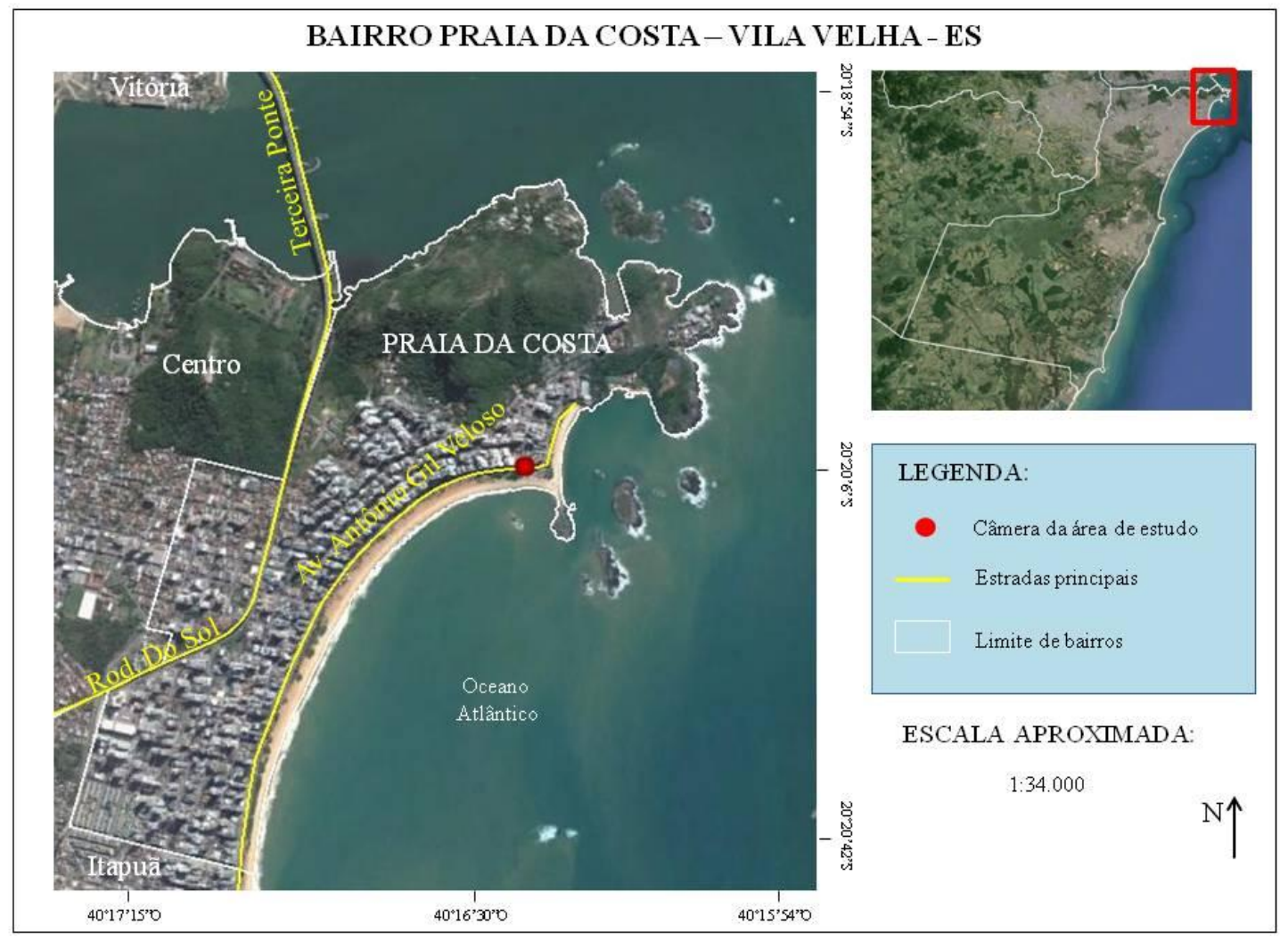

Figura 2. Localização do bairro Praia da Costa e da câmera da área de estudo. Fonte: IJSN (2013).

Em geral, as pessoas entrevistadas que por ali circulavam, incluindo os moradores, não sabiam da presença da câmera destinada a vigiar a área. Elas estavam cientes de que a cidade era vigiada por câmeras, mas ficavam surpresas ao saber que justamente ali havia uma delas. É importante registrar que as câmeras são pequenas, de cor branca, colocadas em postes da mesma cor e numa altura considerável. Ou seja, elas são discretas e os alto-falantes acoplados a algumas delas e que as anunciam só o fazem esporadicamente. Portanto, dificilmente as pessoas estão atentas às câmeras. 
As raras pessoas que sabiam da presença da câmera naquela área eram os comerciantes locais, embora não acreditassem que ela estivesse "funcionando". Na verdade, eles não possuíam nenhum tipo de informação concreta sobre o funcionamento ou não da câmera, mas apenas uma impressão (ou "quase certeza", como costumavam dizer) disso. O verbo "funcionar", para eles, tinha um significado relacionado à incapacidade da câmera servir para resolver os "problemas" a que se propunha.

Neste sentido, quando eram estimulados a dizer por que achavam que aquela câmera não "funcionava", citavam alguns furtos/roubos que haviam sofrido, a utilização inadequada do calçadão (skates e patinetes na ciclovia, bicicletas fora da ciclovia), a presença de vendedores ambulantes, de moradores de rua e o uso de drogas por alguns frequentadores do local. Caso a câmera estivesse de fato "funcionando", eles acreditavam que sua função era justamente a de controlar esses "problemas". Há uma percepção entre os entrevistados de que a mera presença da câmera seria suficiente para que a vigilância do espaço fosse total. Em geral, eles não consideram que existe um trabalho humano por trás nem mesmo desconfiam dos sérios limites impostos à vigilância que discutimos anteriormente.

Se por um lado as câmeras não conseguem "ver tudo", por outro, quando "vêem", não permitem de "resolver" o que seria considerado como "problema", o que desacreditaria sua eficácia aos olhos dos entrevistados na Praia da Costa. As imagens desta câmera da Praia da Costa mostram claramente, por exemplo, pessoas usando drogas, a utilização estimada "inadequada do calçadão" e a presença do comércio dito informal. Evidentemente, estes são "problemas" do ponto de vista dos frequentadores que entrevistamos e por isso a utilização das aspas. Segundo eles, a câmera estaria ali para evitá-los. Não estamos de acordo com a utilização de câmeras para este fim, muito pelo contrário. No caso em tela elas serviriam para alimentar as discriminações e os controles sociais em relação às populações dominadas. Nosso objetivo é apenas demonstrar que esta câmera não "funciona" no sentido esperado por alguns entrevistados, o que interfere diretamente na forma de percepção da vigilância e que, ao mesmo tempo, revela a posição social dos indivíduos entrevistados. 
Se em geral os entrevistados ou não sabiam da presença da câmera ou não acreditavam que ela funcionasse, as perguntas a respeito da sensação de segurança proporcionada por ela ou se algo havia mudado no local após a sua instalação, faziam muito pouco sentido para eles. Elas pareciam tão absurdas, que os entrevistados muitas vezes nem conseguiam respondê-las e ficavam surpresos como alguém poderia abordar a vigilância a partir dessas questões.

No bairro Glória (Figura 3), que conta com uma grande usina de chocolate pertencente à multinacional Nestlé e com muitos comércios de confecções, foi escolhido um espaço vigiado por duas câmeras, relativamente próximas entre si, mas que contemplavam áreas com características distintas: uma delas apresentava uma importante avenida da cidade, diversos bancos e agências financeiras, comércios formais e ditos informais e uma movimentação intensa de pessoas e automóveis; a outra se localizava no "interior" do bairro, as ruas eram mais estreitas, o comércio se restringia à presença significativa de lojas de confecções, muito características do bairro, e a movimentação de pessoas e automóveis era menor.

Neste caso, a "confiança" nas câmeras era ainda menor do que os entrevistados na Praia da Costa. Se em geral as pessoas sabiam que Vila Velha tinha ruas vigiadas e sabiam que o bairro era contemplado por algumas câmeras, elas nem desconfiavam da localização específica delas e ficavam extremamente surpresas quando eu as mostrava, muitas vezes sobre as suas cabeças. No bairro Glória, as câmeras são ainda mais discretas do que na Praia da Costa, pois não possuem o alto-falante acoplado e competem com fios, postes e prédios na paisagem.

No caso do bairro Glória, nem mesmo os comerciantes entrevistados sabiam da presença das câmeras, com poucas exceções. Nestes casos, assim como na Praia da Costa, não acreditavam que "funcionassem”. Não possuíam nenhuma informação concreta a este respeito e as câmeras somente "funcionariam" caso cumprissem com o seu objetivo, que neste caso era evitar os possíveis furtos e roubos das lojas. Um dos comerciantes entrevistados informou que desde que a câmera foi instalada sua loja foi seguidas vezes arrombada durante a madrugada e a câmera em nenhuma ocasião conseguiu 
registrar o ocorrido. Quando solicitamos a entrevista e mencionamos a câmera que fica em frente ao seu estabelecimento, ele logo falou indignado "Mas que não funciona né?!".

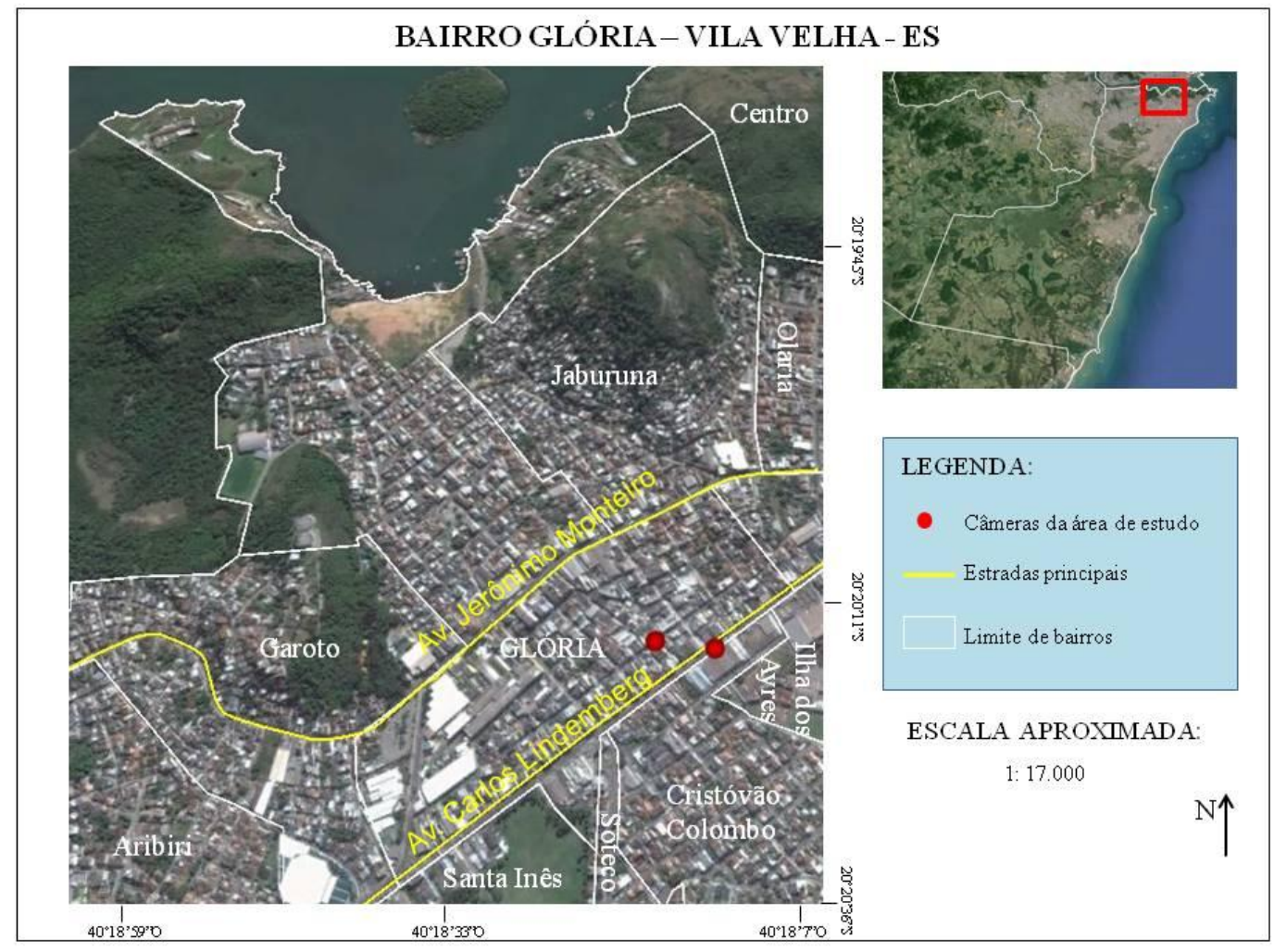

Figura 3. Localização do bairro Glória e das câmeras da área de estudo. Fonte: IJSN (2013).

Considerando a profunda indiferença com que as pessoas lidam com as câmeras no bairro Glória, perguntar se elas garantiam algum tipo de segurança ou se algo havia mudado após a sua instalação era tão absurdo quanto o foi na Praia da Costa. As pessoas vivem como se elas não existissem, o que pode ser atestado, inclusive, considerando o investimento realizado pelos comerciantes em segurança privada: as lojas, em geral, possuem seguranças privados, sistemas de alarme e câmeras de vídeo. Mais uma vez se reitera um discurso do que se espera de uma câmera, que ela "funcione", que ela tenha eficácia policial.

Há apenas uma câmera em Riviera da Barra (Figura 4), bairro de residência das classes dominadas na região denominada Terra Vermelha, situada em uma praça do bairro, em cujas redondezas encontramse alguns estabelecimentos comerciais e algumas residências. A movimentação de pessoas e 
automóveis na área é pouco significativa se comparada às áreas dos demais bairros, aumentando um pouco no final da tarde e início da noite.

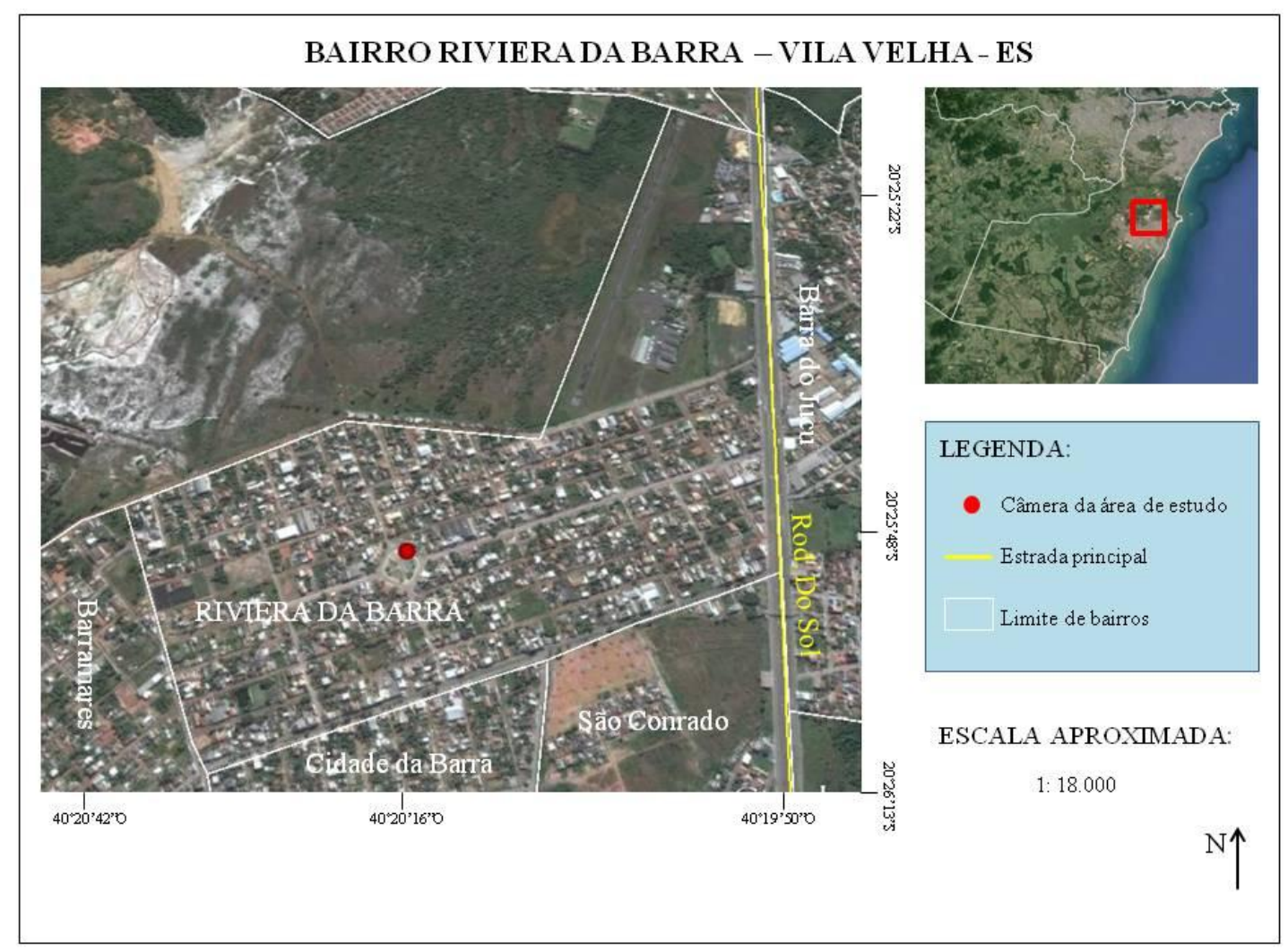

Figura 4. Localização do bairro Riviera da Barra e da câmera da área de estudo. Fonte: IJSN (2013).

O estudo desta área talvez seja o mais significativo dentre os que realizamos na medida em que deixa mais explícito os paradoxos da vigilância. Ao contrário dos outros bairros, em Riviera da Barra as pessoas entrevistadas estão majoritariamente cientes da presença da câmera. Ela se destaca claramente na paisagem e possui um alto-falante acoplado que a anuncia. Por outro lado, considerando que o bairro raramente é atendido pelas políticas públicas, a implantação de um dispositivo "moderno" contrasta com as características socioespaciais locais. Em suma, se a instalação de câmeras na Praia da Costa ou na Glória não representa exatamente uma novidade, em Riviera da Barra a sua implantação foi um "acontecimento".

Porém, mais do que nos outros casos, a falta de "confiabilidade" da câmera de Riviera da Barra é total. Os comerciantes e as pessoas entrevistadas reclamavam que eram vítimas de roubos e furtos, os 
frequentadores da Praça reclamavam do uso de drogas por alguns frequentadores, das depredações e das pessoas que circulam de moto sobre ela. Enfim, não acreditam que a câmera "funcionasse", pois ela não "resolvia" ou, ao menos, não amenizava os "problemas". Muitos dos entrevistados tratavam a vigilância da câmera como uma piada, as crianças riam e zombavam dela quando o alto-falante a anunciava e uma entrevistada me relatou o caso de um amigo que, durante a madrugada, tirou a roupa embaixo da câmera para "provar" que ela não funcionava. Em função dos limites que apresentamos, a câmera de Riviera da Barra não registrava a maior parte dos "problemas", com exceção dos usos de drogas, que eram recorrentemente registrados como ocorrências pelos operadores.

Mas o que a pesquisa em Riviera da Barra revelou de mais importante, foi que a câmera à época de fato não estava funcionando. Embora ela funcionasse normalmente enquanto fazíamos a pesquisa na central de monitoramento, ela deixou de fazê-lo no intervalo de duas semanas em que a pesquisa nas ruas foi iniciada. Alguns entrevistados disseram que a desconfiança sobre o não funcionamento da câmera havia aumentado quando perceberam que o alto-falante havia parado de anunciá-la e verificaram um fio solto pendurado no poste. Entrando em contato com a central, verificamos que de fato a câmera não estava mais funcionando. Esta constatação permitiu ainda verificar na prática como a ausência de manutenção compromete o sistema de vigilância, pois, por pelo menos nos dois meses seguintes, a câmera não funcionou, confirmando a suspeita das pessoas de que aquela câmera não funcionava, agora sem as aspas.

\section{Cidades monitoradas, espaços públicos fragilizados}

Os problemas que constituem obstáculos para uma "vigilância total" e que alimentam a ausência de efeitos aparentes sobre os cidadãos e os seus espaços, como discutimos anteriormente, não impedem que consideremos a vigilância através de câmeras como uma forma de poder. Para tanto, nossa referência é Foucault (2009), para quem o poder não é monopólio de uma suposta classe dominante ou do Estado, e cujo exercício não ocorre de cima para baixo, o que nos permite uma interpretação do poder inteiramente diferente de sua associação habitual com termos negativos, tais como "repressão", “exclusão" e "censura”. Para Foucault, o poder é múltiplo, anônimo, se exerce em rede. Geralmente 
associado a saberes diversos, o poder produz campos de verdade que tomam por objeto os indivíduos isoladamente ou o conjunto de uma população. O objetivo é uma correta administração de suas vidas, de modo a torná-las politicamente dóceis e economicamente aptas.

As câmeras nos remetem à figura arquitetural paradigmática do poder disciplinar, o panóptico, um modelo de vigilância exercido fundamentalmente pelo jogo do olhar (FOUCAULT, 2009). Inicialmente imaginado pelo filósofo Jeremy Bentham como uma arquitetura de vigilância prisional, consistia no seguinte: uma torre central, onde deveria ficar o guarda, estaria rodeada por celas onde estariam trancados os presos, de tal modo que o guarda poderia visualizar todas elas e, o que é mais importante, sem poder ser visto. Sem saber que estavam sendo vigiados, os presos guardariam incessantemente a sensação do controle e aí estaria o ideal de uma vigilância panóptica: não havendo necessidade de um guarda na torre central os próprios indivíduos seriam as engrenagens do poder e do "autocontrole".

Rompendo as barreiras das prisões e de outras instituições fechadas onde ele também funcionava, o panóptico foi imaginado como um modelo de vigilância generalizável por toda a sociedade. A atualização do panóptico parece ser indicada pelos objetos técnicos que nos cercam, particularmente as câmeras de vigilância destinadas a vigiar os espaços públicos: por que não pensar a sala de controle como a torre central e os cidadãos como os prisioneiros?

A utilização do panóptico como referencial teórico faz muito sentido quando consideramos os casos das câmeras que não funcionavam ou das que não eram monitoradas. Não foi exatamente isso que escreveu Foucault (2009), que a vigilância panóptica ideal prescindia da presença do guarda na torre central? No caso das câmeras, bastava que estivessem presentes nos espaços públicos, representando a eterna lembrança do poder, para que as pessoas se sentissem vigiadas, independente do que se passava na sala de controle.

Porém, se o trabalho "por detrás" das câmeras indicava a atualidade do panóptico, a pesquisa realizada nos espaços vigiados mostrou, até certo ponto, os seus limites, considerando que os cidadãos entrevistados, em geral, não sabiam da presença das câmeras (como vimos, o funcionamento do panóptico dependia de se inculcar nas pessoas a percepção da vigilância por meio da presença explicita 
do controle) e eram indiferentes à vigilância ou a consideravam "ineficaz". Porém, de qualquer forma, a multiplicação de câmeras alimenta e atualiza um estado de controle permanente que de alguma maneira exerce influência sobre a vida cotidiana. E, através dos olhares que se multiplicam, a vigilância traz ainda consigo o ideal panóptico de "tudo saber", de tudo ver e revela os olhares daqueles que se colocam do lado dos atores dominantes sobre os dominados.

Neste sentido, ela representa uma ameaça à "vitalidade" dos espaços públicos. Para Souza (2008), o espaço público em seu sentido geográfico (substrato, território, lugar) pressupõe uma cena pública (ou esfera pública) que tem como requisito indispensável um "piso mínimo" de liberdade formal e real, não obstante existam gradações de consistência. Para o autor "[...] pode-se falar de esfera pública e, por extensão, de espaço público, apenas diante de um mínimo (dificilmente passível de delimitação mais rigorosa, mas ainda sim perceptível) de autonomia individual e coletiva” (SOUZA, 2008, p. 83). Quanto maior for essa autonomia, assim como o nível de acessibilidade e pluralismo, maior será o nível de consistência da esfera pública e, consequentemente, o nível de "vitalidade" dos espaços públicos.

Não se trata apenas, segundo Serpa (2007), de uma acessibilidade estritamente física, mas também simbólica, pois "[...] caso seja certo que o adjetivo "público" diz respeito a uma acessibilidade generalizada e irrestrita, um espaço acessível a todos deve significar, por outro lado, algo mais do que o simples acesso físico a espaços "abertos" de uso coletivo" (SERPA, 2007, p. 16). Deve significar, pois, mais do que a presença da pluralidade, a sua aceitação e legitimidade.

O que está por trás da fragilização dos espaços públicos "[...] é o encolhimento de margens de manobra, a deterioração da sociabilidade e da civilidade e as restrições ao exercício da cidadania - em suma, ameaças e limitações à autonomia, tanto individual quanto coletiva" (SOUZA, 2008, p. 84). Isto porque, em uma fobópole, a vida pública se enfraquece (o autor cita os limites à "liberdade" a partir dos casos dos "condomínios exclusivos" e das favelas territorializadas tiranicamente pelos traficantes de drogas, poderíamos dizer que são também territorializadas pelo Estado via policia). Como resultado, por causa do medo, espaços públicos deixam de ser frequentados ou, então, passam a 
ser monitorados, alimentando também o "declínio" da esfera pública. 0 autor resume assim as virtuais ameaças representadas por uma cidade monitorada:

[...] os dispositivos de controle e monitoramento, que deveriam supostamente servir para garantir um nível satisfatório de qualidade de vida, colaborarão por sabotar a concretização dessa intenção, ao menos parcialmente, ao restringirem a privacidade - e, no limite, ao se constituírem em uma ameaça à liberdade e à espontaneidade, ao exercício da autonomia. Recordando o dito popular, veste-se um santo (muito imperfeitamente, aliás) mas, para isso, despe-se outro. Trocar liberdade por segurança, coisa que muitos já dão, resignadamente, como inevitável, é um mau negócio (SOUZA, 2008, p. 86).

O que nos parece importante nessa citação é a menção à redução da privacidade (ou da individualidade, termo que preferencialmente utilizaremos daqui em diante) e a consideração dos perigos que os dispositivos de vigilância potencialmente representam à liberdade e à cidadania. Não é porque a vigilância através de câmeras possui uma série de limites, nem mesmo porque os espaços públicos que pesquisamos ainda são bastante frequentados (embora existam algumas restrições de dias e horários) que devemos "baixar a guarda" diante de fenômenos que merecem ser pintados em cores fortes, e não em tons pastéis, conforme assinala Souza (2008).

O que o autor está querendo dizer, nos parece, é que uma área monitorada (vigiada por câmeras, por exemplo) é mais um obstáculo que impossibilita que um espaço público se realize plenamente, pois as condições para restrição da autonomia (individual e coletiva) estão potencialmente postas. Por outro lado, se a mera presença de uma câmera e o muro simbólico que ela ajuda a erguer atualizam constantemente a suspeição e o estigma, particularmente sobre "grupos indesejáveis", ela sabota outra condição fundamental dos espaços públicos, que é a diversidade e o pluralismo. É neste sentido que podemos dizer que o controle representado pelas câmeras diminui a vitalidade, enfraquece, enfim, fragiliza os espaços públicos e coletivos.

\section{O estigma colocado sobre os dominados}


Embora sejam ferramentas destinadas a vigiar os espaços públicos e a população em geral, as câmeras possuem pelo menos em parte alvos específicos. No caso de Vila Velha eram os jovens de bairros populares. Tanto nos bairros em que residiam como nos casos em que circulavam pelas ruas de outros bairros da cidade, esses jovens, geralmente reunidos em grupos, representavam os alvos favoritos daqueles que operavam as câmeras. Através das imagens produzidas pelas câmeras, os operadores os acompanhavam por longos períodos, independente do comportamento que apresentassem. $\mathrm{O}$ trabalho dos operadores era facilitado porque os jovens pobres brasileiros possuem um código de autoafirmação relacionado ao vestuário. Utilizando bermudas largas, camisas de times de futebol, bonés e cordões, eram facilmente reconhecíveis pelas ruas da cidade.

Os jovens aos quais nos referimos simbolizam aquilo que poderíamos chamar de "inimigo interno" do Estado brasileiro, o Outro, que já não é mais o subversivo perseguido durante o regime militar que dominou o Brasil entre os anos de 1964 e 1984. Esse “inimigo" passou a ser o "marginal", o "bandido" ou o morador de rua, tidos como elementos (elemento era uma palavra muito utilizada pelos operadores e pela polícia para se referir aos que eles designam como "suspeitos") que contaminariam, poluiriam e quebrariam as regras sociais, provocando a "desordem" das cidades brasileiras. São alvos constantes de repressão, de estigmas e preconceitos nos seus próprios espaços de moradia, mas também por onde circulam. A história brasileira registra uma série de abusos por parte da polícia brasileira em relação à população pobre, bem como da iniquidade das violências as mais graves (homicídios e tentativas de homicídios) que atingem particularmente os homens jovens pobres e negros morando nos espaços “periféricos”, como atestam Zanotelli et. al (2011) para o caso do Espírito Santo.

Portanto, a vigilância através de câmeras parece atualizar e, principalmente, alimentar o estigma depositado sobre a população dominada. Se durante as entrevistas nem sempre as falas dos operadores revelavam os alvos da vigilância (eles afirmavam que o "comportamento das pessoas" era o que determinava isso) a prática do monitoramento o fazia. O "bandido", para eles, tinha um perfil. E esse perfil constituía o estereótipo do "criminoso" geralmente associado ao jovem pobre da periferia. 
Constituía uma situação comum que os operadores acompanhassem esses jovens enquanto estes caminhavam pelas ruas dos bairros das classes dominantes, como a Praia da Costa, ou comerciais, como a Glória e o Centro, mesmo que não demonstrassem nenhum tipo de comportamento considerado "suspeito". Assim como eram frequentemente monitorados nos bairros mais pobres, como Riviera da Barra, principalmente quando estavam reunidos em grupos, ou mesmo quando individualmente estavam próximos aos comércios destes bairros, na maioria das vezes aguardando alguém que havia entrado no estabelecimento por um motivo qualquer. Neste último caso, era nítido o desconforto do operador quando uma suspeita alimentada por alguns minutos se transformava logo em seguida em constrangimento e frustração quando as pessoas saíam andando calmamente, obrigando-o a encontrar outra alternativa de monitoramento.

Além dos jovens pobres, eram alvos das câmeras também outros grupos de "indesejáveis", como as prostitutas e os usuários de drogas. Mas nestes casos não se tratava exatamente de grupos considerados "suspeitos". No caso das prostitutas, tratava-se de um monitoramento no sentido de zombaria, como parte das estratégias de monitoramento informal por parte dos operadores. Em relação aos usuários de drogas, tratava-se de um monitoramento no sentido de produtividade, pois o uso de drogas era registrado como uma ocorrência.

O fenômeno de diferenciação dos alvos específicos da vigilância nos interroga sobre a utilização das câmeras enquanto ferramentas "higienizadoras", ou seja, se as imagens das câmeras poderiam ser utilizadas para expulsar determinados grupos sociais de determinadas áreas. Trabalhos como os de Firmino e Trevisan (2012) e Oliva (2013), que realizaram estudos de caso para a cidade de Curitiba, no sul do Brasil, sugerem a utilização de câmeras enquanto potenciais ferramentas de abordagem, exclusão e segregação. Articulado à polícia e à Secretaria de desenvolvimento Urbano da Cidade, o videomonitoramento pode ser utilizado como um sistema que objetiva "limpar" as áreas monitoradas da presença de grupos indesejáveis, como as populações pobres ou os vendedores ambulantes. Nesse sentido, as "opiniões" dos vigias é uma exata réplica daquilo que é esperado pelos entrevistados nos bairros que citamos anteriormente. 
Mas não é só no Brasil que isso acontece. A partir de um estudo de caso que realizaram no centro da cidade de Lyon, na França, Martinais e Bétin (2004) mostram como a utilização de câmeras nessa cidade, sob a justificativa de combate ao crime, está relacionada à construção social dos desvios que recai sobre a população periférica, composta, em grande parte, por imigrantes ou descendente de imigrantes oriundos do norte da África. Suas atitudes, movimentos corporais ou códigos de vestuário específicos causam incômodo aos moradores e comerciantes que fazem pressão política para que as câmeras sejam usadas como ferramentas que auxiliem o trabalho da polícia para que esses grupos sejam punidos. Neste caso, a prática de crimes é um mero detalhe: o importante é que Lyon não perca sua vocação internacional, que os turistas continuem chegando e que o consumo se realize plenamente. O que importa, portanto, não é a vigilância geral do espaço público a fim de evitar ou reprimir atos de delinquência, mas o levantamento correto das pessoas que se deseja punir.

As câmeras de Vila Velha, porém, não são diretamente usadas para fins segregacionistas. Nem os alvos específicos da vigilância, nem os moradores de rua e nem mesmo os vendedores ambulantes são aparentemente incomodados em suas práticas cotidianas a partir dos monitoramentos das câmeras. Eles são permanentemente registrados pelas câmeras, mas, ao que parece, a administração atual da prefeitura de Vila Velha não teria nenhum interesse explicito e nem meios de utilizar as câmeras enquanto ferramentas explicitamente "higienizadoras".

Embora Vila Velha seja uma cidade que apresenta fortes marcas de segregação socioespacial, as práticas cotidianas que observamos durante a pesquisa mostram certas disputas das áreas centrais da cidade. De certa maneira, a circulação de pessoas pobres por essas áreas, bem como a presença dos moradores de rua e dos comércios informais "desafiam" o espaço social da "modernidade", embora, evidentemente, ainda numa relação de subordinação.

Nas entrevistas que realizamos com vendedores ambulantes, percebemos que trabalhavam quase livremente (alguns relataram eventuais abordagens policiais, mas nunca relacionadas às câmeras) nas ruas do bairro Glória e na orla da Praia da Costa sem se preocuparem com a presença das câmeras. Muitos deles, inclusive, nem sabiam da presença delas. 
Durante o trabalho de observação "por detrás" das câmeras, observamos apenas um caso da utilização explicita das câmeras contra os "indesejáveis". Um vendedor ambulante foi proibido de comercializar cachorros-quentes em uma towner em frente a uma casa noturna de Itapoã, um bairro das classes médias de Vila Velha, por estar, supostamente, em situação irregular. A proibição ocorreu porque o dono da casa noturna tinha uma importante influência política. Neste caso, o videomonitoramento serviu de justificativa para que a Guarda Municipal exigisse a retirada do vendedor ambulante. A iniciativa, portanto, não partiu diretamente do videomonitoramento, que serviu apenas de "prova", no sentido de que a atividade "ilegal" estava sendo registrada.

Se as câmeras não cumprem a função de segregar, elas não atendem aos desejos de parte dos moradores do bairro Praia da Costa. Os usuários de drogas, os moradores de rua e os comerciantes informais eram motivos de reclamações frequentes. Mas nada se comparava ao incômodo causado pelo o que eles chamam de "invasão" da praia pela periferia nos finais de semana, principalmente aos domingos. Nas entrevistas realizadas, era evidente o desconforto que essa situação causava e muitos deles afirmaram que só frequentavam a praia e o calçadão durante a semana. Nos finais de semana preferiam ficar em casa. O desconforto causado pela presença de pessoas que não são seus iguais e como essa situação interfere na maneira como utilizam a praia ficam explícitos nas passagens a seguir, retiradas de entrevistas realizadas com moradores e frequentadores da Praia da Costa:

Caminho no calçadão todo dia duas horas por dia e nos finais de semana frequento a praia. Mas os moradores daqui não frequentam a praia nos finais de semana não porque a periferia invade aqui [...] Acho a orla tranquila, só sinto um pouco de medo nos finais de semana (Entrevista com J., transeunte e morador da Praia da Costa, 12/11/2014).

As linhas de ônibus todas vêm para a Praia da Costa, toda a periferia vem pra cá, a ralé toda. Domingo eu nem vou à praia na parte da tarde por causa da sujeira, os moradores nem descem no Domingo à tarde (Entrevista com E., morador, transeunte e diretor da associação de moradores do bairro Praia da Costa, 18/11/2014).

Eu me incomodo com a presença de estranhos que vêm para cá de ônibus de outros bairros (Entrevista com T., moradora e frequentadora do calçadão da Praia da Costa, 14/10/2014). 
As passagens acima são ainda mais preocupantes quando descobrimos que nenhum dos três entrevistados sofreu qualquer tipo de problema, como furtos, roubos ou agressão, por exemplo, que poderia justificar, segundo as visões de mundo simplistas e simplificadoras que têm, esses receios. Os seus medos e incômodos frente a pessoas "estranhas", a "ralé", como dizem, é apenas o medo da diferença, da heterogeneidade, da mistura que a cidade ainda proporciona. A "segurança" aparente dos moradores da Praia da Costa só ocorre nos dias da semana quando ainda podem estar entre iguais e o Outro ainda não é uma ameaça.

Neste sentido, foi esclarecedor o documento apresentado por um dos diretores da associação de moradores do bairro, que trazia sugestões à prefeitura para melhorias no bairro. Dentre elas, a mais significativa era, sem dúvida, a que propunha a mudança de trajetos dos ônibus que faziam as linhas que ligavam a Praia da Costa aos bairros mais pobres do município, uma tentativa de deslocar as pessoas pobres para as praias vizinhas, como Itapoã e Itaparica, tornando explícito o incômodo causado por eles. No documento, constavam ainda sugestões que visavam limitar os trabalhos dos vendedores ambulantes e da comunidade de pescadores que havia na praia.

Portanto, não devemos nos enganar. Se no caso de Vila Velha a vigilância a partir de câmeras não é utilizada de maneira explicita e predominante para fins segregacionistas isto ocorre porque este não é assunto por ora de interesse da administração atual da cidade. Essa função está virtualmente posta, bastando apenas o acionamento da vigilância, quando o assunto for de interesse. Neste caso, a adesão de parcelas dos moradores a esse fim é praticamente certa.

Porém, se de maneira explícita as câmeras não cumpriam função segregadora, os próprios motivos que levavam as pessoas a afirmarem que as câmeras não estavam "funcionando" revela o interesse que os entrevistados tinham para que elas fossem utilizadas enquanto ferramentas de controle social. Como vimos, o desejo de controle era direcionado a determinados grupos sociais que supostamente "perturbavam a ordem", tais como moradores de rua, usuários de drogas e comerciantes informais. Se o controle desses grupos sempre foi uma necessidade de parcela da população, as câmeras pareciam atualizar permanentemente o estigma sobre estes grupos, alimentando um estado de controle entre os 
cidadãos, que admitem e desejam a virtual função de controle delas. Mesmo que simbolicamente, as câmeras segregam.

Fortalecendo os muros simbólicos que separam os "bons" dos "maus" cidadãos, as câmeras nos remetem ao que Foucault (2009) menciona sobre a normalização numa sociedade de tipo disciplinar. De certa forma, os "indesejáveis" que se fazem presentes nos espaços que pesquisamos estão inadequados à regra, que seria o comércio formal, as famílias, o lar e a não utilização de drogas. Comparados à regra, ao padrão, eles se diferenciam e estão simbolicamente excluídos. As câmeras representam a eterna lembrança de uma suposta homogeneização dos espaços.

\section{O desrespeito à vida cotidiana}

A primeira coisa a ser dita em relação ao direito à individualidade dos cidadãos num contexto de cidades vigiadas relaciona-se à capacidade de aproximação das câmeras. Num raio de aproximadamente trezentos metros, as câmeras produzem imagens de excelente qualidade que permitem a leitura de placas de carro, a distinção da marca de um batom no interior de uma bolsa, a verificação dos modelos de roupas em vitrines de lojas, a distinção entre o uso de maconha ou crack e, principalmente, a visualização em detalhes do que as pessoas fazem bem como a distinção nítida de seus rostos.

Em geral, quando estamos nas ruas acreditamos que a distância em relação às câmeras serve de proteção à nossa privacidade. Como inclusive constatamos nas entrevistas feitas com as pessoas que frequentam os espaços públicos, a violação da privacidade raramente é motivo de preocupação também porque as câmeras estão "longe". Uma visita à central onde as câmeras são monitoradas, porém, surpreende e desfaz a percepção anterior dos entrevistados transeuntes em relação à vigilância.

A ferramenta de zoom, quando acionada, relativiza as distâncias em relação à câmera. Com a câmera travada, ela permite uma aproximação constrangedora. E só quem sabe disso são as pessoas que trabalham diretamente no monitoramento ou aquelas que tiveram a oportunidade de, por pelo menos uma vez, conhecer o sistema. O primeiro contato causa impacto. Talvez seja por isso que, ao contrário 
das pessoas entrevistadas nas ruas, os operadores das câmeras sentem o peso da individualidade violada, quando, por exemplo, evitam frequentar certos espaços vigiados.

A individualidade é acintosamente violada pelo sistema de vigilância de câmeras de Vila Velha. Os gestores do sistema estabelecem uma rígida divisão entre espaços privados e públicos. Enquanto as pessoas são relativamente preservadas em seus espaços residenciais, nos espaços públicos não existe nenhum tipo de restrição à vigilância. Veja o que disseram os gestores sobre a essa diferença no que se refere à privacidade dos cidadãos:

Até onde sabemos não existe relato de constrangimento, até porque os nossos servidores tem um treinamento de que não pode invadir a residência do munícipe de forma nenhuma, porque acaba tirando a privacidade, isso pode dar um processo contra a prefeitura. Eles são treinados e são operadores de vias públicas, eles devem acompanhar as demandas da rua (Entrevista com C., gestor do videomonitoramento de Vila Velha, 22/05/2014).

Muito pelo contrário (...). Mesmo porque eles [os cidadãos] não têm acesso às imagens. Você mesmo viu aquelas imagens [referência às imagens de sexo e furto em vias públicas que eles haviam mostrado em outra ocasião], se aquelas pessoas tivessem acesso ficariam constrangidas, mas elas não estavam na casa delas, estavam na rua (Entrevista com H., operador e membro da equipe administrativa do videomonitoramento, 22/05/2014).

Quando mencionamos a capacidade de aproximação das câmeras, um dos gestores continuou:

\footnotetext{
Ela tem um limite, dependendo da qualidade da câmera ela pode até distorcer as imagens. Nessa questão de achar bom ou não, o que não pode é instalar câmeras no banheiro, aí sim dessa forma está constrangendo as pessoas, as pessoas podem estar fazendo as necessidades dela, agora se está fora, onde todos transitam, não há nada que impeça, fora da residência (Entrevista com C., gestor do videomonitoramento de Vila Velha, 22/05/2014).
}

Essa nítida diferenciação entre o público (as ruas), onde tudo pode, e o privado (as casas, o banheiro), onde a sociedade e o Estado não podem penetrar, que transparece nas falas acima, é típica da sociedade brasileira. Como diz Da Matta (1997), em casa somos "supercidadãos" e na rua somos "subcidadãos". As "muitas formas de cidadania" verificadas no Brasil ainda privilegiam relações 
pessoais e familiares que muitas vezes desprotegem os cidadãos em ambientes públicos. Em suma, na "rua", os cidadãos brasileiros estão expostos, é o espaço onde tudo pode. Embora essa política binária de vigilância seja, em geral, seguida pelos operadores, há algumas coisas a serem ditas.

Em primeiro lugar, em alguns casos o desrespeito à privacidade acontecia também nos espaços residenciais. Algumas câmeras mal programadas "invadiam" as residências das pessoas através das janelas. Como não existia serviço de manutenção, o problema não podia ser resolvido. Por outro lado, em muitos lugares o monitoramento das câmeras permitia a visualização de varandas e terraços. Em alguns casos, os operadores monitoravam esses espaços sem nenhum constrangimento; em outros, mais comuns, o monitoramento das ruas exigia que se "passasse" sobre esses espaços.

Embora não se tenha presenciado situações de monitoramento em que os operadores estivessem interessados em registrar o interior das residências para fins específicos, alguns entrevistados disseram que isso já ocorreu. Ficou conhecido o caso, por exemplo, de um operador que sempre registrava um casal que sempre fazia sexo na mesma hora e local: às oito horas da noite, na varanda de um apartamento. Mas, como dito anteriormente, existia uma relativa preservação dos espaços residenciais. 0 problema era mais grave nos espaços públicos: ali, tudo era permitido.

Se na rua tudo podia, os operadores não faziam a menor cerimônia em aproximar as imagens que mostravam detalhadamente os rostos e os gestos das pessoas, independentemente do que elas estivessem fazendo. As pessoas eram escolhidas ao acaso enquanto caminhavam pelas ruas ou estavam sentadas em praças, por exemplo, e eram "invadidas" pelas câmeras. Mas essa invasão se tornava mais característica quando as pessoas que estavam em bares e festas eram monitoradas.

Tratava-se de uma das estratégias informais de monitoramento para "matar o tempo". Nestes casos, os operadores podiam passar horas observando as movimentações em bares, entradas de casas noturnas ou postos de gasolina, ponto de encontro de jovens antes das festas. Fazendo o tempo passar, os operadores bisbilhotavam a vida alheia. O enquadramento das pessoas era acompanhado por comentários, geralmente com o operador que estava ao lado, e, às vezes, com a sala inteira, que 
especulavam sobre o que as pessoas bebiam, fumavam, enfim, o que elas faziam. Presenciamos também situações em que a vigilância de bares ocorria por mera diversão, por exemplo, quando pessoas nitidamente bêbadas arrancavam gargalhadas dos operadores enquanto dançavam.

Mas talvez os casos mais problemáticos da vigilância fossem os registros de relações sexuais. Várias ocorrências eram feitas em relação a isso e os arquivos eram armazenados. Tratava-se de casais fazendo sexo na praia e, principalmente, relações sexuais com prostitutas. As ocorrências registradas eram armazenadas em arquivos que podiam ser abertos por todas as pessoas que trabalhavam na sala de controle. As ocorrências que registravam relações sexuais eram as que despertavam maior curiosidade entre as pessoas. Independentemente do turno e por quem tinham sido feitas, o certo é que todas as pessoas que trabalhavam na sala de controle veriam aqueles vídeos como mais uma estratégia, a preferida delas, para fazer o tempo passar, revelando um voyuerismo perverso.

Nas ruas, a vigilância também era utilizada para fins pessoais. Uma das operadoras, por exemplo, fazia uso das câmeras para monitorar o namorado que trabalhava como motorista em um caminhão de guincho pelas ruas de Vila Velha. Observamos ainda que um operador utilizava uma das câmeras localizada no bairro Praia da Costa para monitorar a mulher e o filho que brincavam em um parquinho na areia da praia, enquanto, orgulhoso, mostrava a cena para os demais operadores.

No Brasil, não há legislação federal que trate da relação específica entre privacidade e vigilância através de câmeras de vigilância. Apenas alguns Estados brasileiros, como São Paulo, versam, mesmo que insuficientemente, sobre a privacidade relacionada às câmeras, como é o caso da obrigatoriedade de avisos em locais monitorados. O convênio anterior entre o Estado do Espírito Santo, que destinou parte dos recursos financeiros para a expansão do sistema de câmeras, e a prefeitura da cidade de Vila Velha, também obrigava a sinalização visual dos locais monitorados, embora o convênio atual não faça essa exigência.

Em termos federais, o tema da privacidade só aparece em contextos mais amplos, como no artigo $5^{0}$ da constituição federal que em seu inciso X afirma que: "São invioláveis a intimidade, a vida privada, a 
honra e a imagem das pessoas, assegurando o direito a indenização pelo dano material ou moral decorrente de sua violação" (BRASIL, 1988).

É evidente que o inciso acima citado está sujeito a inúmeras interpretações e muitas delas fariam distinções binárias no sentido de que a privacidade só deve ser respeitada em ambientes privados, como é o caso da política de vigilância da prefeitura de Vila Velha em relação às câmeras. Mas, poderíamos nos perguntar: será que a nossa intimidade, ou pelo menos um dos aspectos dela, não deveria ser preservada também nas ruas? As câmeras, da forma como são operadas, não estariam violando a nossa intimidade? E a nossa vida privada, será que não a carregamos para a rua? A honra e a imagem de uma pessoa não estariam sendo violadas quando imagens dela fazendo sexo, por exemplo, são vistas cotidianamente numa sala de controle de videomonitoramento, mesmo que elas somente sejam visualizadas neste âmbito restrito?

O nosso objetivo não é responder as questões acima, mas tão somente problematizar a maneira como é entendida a privacidade, a intimidade e liberdade no caso brasileiro. Parece que no caso dos países europeus, onde a vigilância através de câmeras já é algo mais consolidado, os debates em torno dessas questões pelo menos existem, conforme nos mostra o trabalho de Gras (2004).

Muitos Estados europeus reconhecem que a vigilância através de câmeras em espaços públicos gera conflitos com o direito à privacidade e assim a regulamentação passa a ser necessária e desejável. Tanto para os que desejam instalar sistemas privados de monitoramento que contemplem espaços públicos quanto para as administrações públicas que desejam implantar sistemas públicos de monitoramento, as restrições contemplam questões referentes à privacidade, o que não parece ser 0 caso brasileiro.

Mas, como mostra Gras (2004), como a legislação está sujeita a muitas interpretações, a implantação de sistemas de vigilância através de câmeras geralmente consegue superar as barreiras legislativas europeias. Particularmente após os atentados ao World Trade Center e ao Pentágono, em Nova York, 
nos Estados Unidos, em setembro de 2001, que acabam por justificar todo o investimento em estratégias de segurança que, por sua vez, alimenta a vigilância através das câmeras.

Ainda no que se refere à individualidade atingida pelas câmeras, parece haver uma preocupação por parte da prefeitura no que se refere ao controle das imagens. As imagens produzidas pelas câmeras são de "sigilo absoluto" e só podem ser solicitadas em casos de crimes, por exemplo, mas o acesso é exclusivo da polícia civil para casos de investigação. Portanto, os funcionários do videomonitoramento não têm acesso às imagens para fins pessoais e o uso de equipamentos eletrônicos na sala de controle era restringido particularmente em função disso. Gravar, copiar ou tirar fotos das imagens, são, portanto, práticas ilegais, salvo em casos de investigação da polícia, como dito acima. Inclusive, o trabalho que realizamos na central onde as câmeras são monitoradas só foi autorizado a partir da elaboração de um documento no qual precisávamos deixar explícito o nosso comprometimento em não salvar, copiar ou registrar qualquer tipo de arquivos de imagens. No fundo, essa era a única preocupação.

Mas uma coisa que nos intrigava enquanto acompanhávamos o trabalho realizado na central era a facilidade que existia em se apropriar dos arquivos produzidos. Embora não tenham sido observados casos deste tipo, copiar arquivos de imagens era uma virtual ameaça que poderia se realizar a partir de qualquer pessoa que tivesse acesso à central.

Embora não haja nenhuma legislação específica no Brasil que regulamente a utilização de imagens produzidas por câmeras em vias públicas, o controle das imagens pela prefeitura de Vila Velha parece atender às exigências de proteção ao cidadão, que só ocorre, mais uma vez, em termos gerais, como é o caso da Lei Federal nº 10.406, que, em seu artigo 20, diz: "Salvo se autorizadas, ou se necessárias à administração da justiça ou à manutenção da ordem pública, a divulgação de escritos, a transmissão da palavra, a publicação, a exposição ou a utilização da imagem de uma pessoa poderão ser proibidas, a seu requerimento e sem prejuízo da indenização que couber, se lhe atingirem a honra, a boa fama ou a respeitabilidade, ou se destinarem a fins comerciais" (BRASIL, 2002). 
No caso do município de Vila Velha, a política em relação às imagens foi definida a partir do convênio estabelecido entre a prefeitura e o Estado do Espírito Santo. As imagens devem permanecer registradas por um período mínimo de quarenta e cinco dias. As imagens das ocorrências consideradas relevantes pela equipe administrativa são mantidas em arquivo por tempo indeterminado, enquanto todas as outras imagens são eliminadas após o prazo mínimo de arquivamento.

\section{CONSIDERAÇÕES FINAIS}

No caso da cidade de Vila Velha, a vigilância através de câmeras de vigilância encerra muitos paradoxos. Alguns fatores relacionados ao trabalho "por detrás" das câmeras (câmeras que não são monitoradas, baixos salários, empregos instáveis, ausência de manutenção dos equipamentos do sistema) impõem importantes limites à vigilância. Por outro lado, esses limites ajudam a explicar a maneira surpreendentemente indiferente com que as pessoas lidam com a vigilância e a ausência aparente de efeitos sobre os espaços vigiados. Com isso, questionamos a utilização de câmeras para fins de segurança, mas também determinada abordagem puramente teórica sobre o controle, que o nosso estudo empírico contribui para relativizar.

Porém, não devemos nos iludir. A vigilância através de câmeras é mais um obstáculo na constituição de espaços públicos genuínos na medida em que fragiliza condições indispensáveis para a existência de uma esfera pública que é condição indispensável para que eles existam. Em Vila Velha, esses obstáculos estão virtualmente postos em razão das ameaças à pluralidade e à liberdade, bem como em relação ao desrespeito à individualidade em espaços públicos e privados.

A vigilância possui alvos específicos, particularmente os jovens pobres da periferia. Ela atualiza, assim, um aspecto importante da sociedade brasileira que é a criminalização da pobreza. Independentemente de seus comportamentos, esses jovens constituem os "suspeitos" da cidade na medida em que, no Brasil, o “criminoso" possui um perfil. Embora eles sejam constantemente monitorados, esses jovens, assim como outros grupos de “indesejáveis" (prostitutas, travestis, vendedores ambulantes, moradores de rua) não sofrem aparentemente nenhum tipo de abordagem 
como resultado da utilização de câmeras. Nossa pesquisa em Vila Velha, portanto, não indica a utilização das câmeras enquanto ferramentas de segregação explícitas, embora isso não ocorra simplesmente porque não foi de interesse da administração atual fazê-lo pelo menos no período em fizemos o nosso trabalho. As condições para tanto estão postas e podem ser colocadas em prática a qualquer momento. No entanto, as câmeras de Vila Velha segregam de uma maneira sutil: elas constituem muros simbólicos que atualizam o estigma sobre os grupos sociais que fogem à regra, como os usuários de drogas, os moradores de rua e o comércio dito informal, o que foi revelado quando descobrimos que do ponto de vista dos entrevistados as câmeras não "funcionavam" pois não eram capazes de controlá-los.

A utilização de câmeras em Vila Velha possui um acintoso desrespeito à vida cotidiana dos cidadãos. Embora os espaços privados sejam relativamente preservados, algumas câmeras "invadem” janelas, varandas e terraços. Mas são nos espaços públicos que os desrespeitos se tornam mais flagrantes. A capacidade de aproximação de uma câmera permite observar em detalhes tudo o que se passa em seu raio de alcance. A aproximação é constrangedora, e os operadores não possuem escrúpulos: os cidadãos são monitorados para fins informais nas praias, em bares e em entradas de casas noturnas com o simples propósito de saber o que estão fazendo. Por outro lado, as câmeras são utilizadas para fins pessoais, como o acompanhamento de familiares, por exemplo. Finalmente, cenas de sexo explícito são registradas e os arquivos circulam indiscriminadamente entre os funcionários do sistema enquanto trabalham. Revela-se, assim, um voyuerismo dos agentes trabalhando para o Estado, favorecendo uma prática de controle que pode, eventualmente, servir para toda sorte de abusos possíveis.

\section{REFERÊNCIAS}

BRASIL. Constituição (1988). Constituição da República Federativa do Brasil. Disponível em: http://www.planalto.gov.br/ccivil_03/constituicao/constituicao.htm. Acesso em 09 fev. 2015.

BRASIL. Lei nº 10.406, de 10 de janeiro de 2002. Casa Civil. Disponível em:

http://www.planalto.gov.br/ccivil_03/leis/2002/110406.htm. Acesso em 09 fev. 2015.

BRASIL. Portaria nº 1.885, de 2 de dezembro de 2013. Ministério do Trabalho e Emprego. Disponível em: http://portal.mte.gov.br/legislacao/2013-1.htm. Acesso em 06 fev. 2015.

DAMATTA, Roberto. A casa e a rua: espaço, cidadania, mulher e morte no Brasil. Rio de Janeiro: Rocco, 1997. 163p. 
DELEUZE, Gilles. Conversações. São Paulo: Editora 34, 2007. 232p.

GOMES, Paulo César da Costa. A condição urbana: ensaios de geopolítica da cidade. Rio de Janeiro: Bertrand Brasil, 2002.

Espaços públicos: um modo de ser no espaço, um modo de ser do espaço. In: CASTRO, Iná Elias de; GOMES, Paulo César da Costa; CORREA, Roberto Lobato (Org.). Olhares geográficos: modos de ver e viver o espaço. Rio de Janeiro, Bertrand Brasil, 2012.

FIRMINO, Rodrigo José; TREVISAN, Elisa. Watching the watchers in the monitoring public spaces in Curitiba, Brazil. Surveillance and Society, vol. 10, n. 1, p. 28-41, 2012. Disponível em: www.surveillance-and-society.org/cctv. Acesso em 09 mar. 2015.

FOUCAULT, Michel. Microfísica do poder. 26. ed. Rio de Janeiro: Graal, 2008. $295 \mathrm{p}$.

Vigiar e punir. História da violência nas prisões. 36. ed. Petrópolis: Vozes, 2009. 291p.

GRAS, Marianne L. The legal regulation of cctc in Europe. Surveillance and Society, vol. 2. N. 2-3. P. 216-229, 2004. Disponível em: www.surveillance-and-society.org/cctv. Acesso em 09 fev. 2015.

IBGE, Instituto Brasileiro de Geografia e Estatística - Censo demográfico 2010.

MARTINAIS, Emmanuel; BÉTIN, Christophe. Social aspects of CCTV in France: the case of the city of Lyons. Surveillance and Society, vol. 2, n. 2-3, p. 361-375, 2004. Disponível em: www.surveillance-and-society.org/cctv. Acesso em 09 mar. 2015.

OLIVA, Diego Coletti. Entre olhos eletrônicos e olhares humanos. 151f. Dissertação (Mestrado em Sociologia) - Pós Graduação em Sociologia, Universidade Federal do Paraná, Curitiba, 2013.

SERPA, Angelo. 0 espaço público na cidade contemporânea. São Paulo: Contexto, 2007.

SMITH, J. D. Smith. Behind the screens: examining constructions of deviance and informal practices among CCTV control Room operators in the UK. Surveillance and Society, vol. 2, n. 2-3, p. 376-395, 2004. Disponível em: www.surveillanceand-society.org/cetv. Acesso em 04 fev. 2015.

SOJA, Edward W. Postmetrópolis. Estudios críticos sobre las ciudades y las regiones. Madrid: Traficantes de sueños, 2008. $594 \mathrm{p}$.

SOUZA, Marcelo Lopes de. Fobópole. O medo generalizado e a militarização da questão urbana. Rio de Janeiro: Bertrand Brasil, 2008. 288p.

VIDEOMONITORAMENTO ajuda na prisão de suspeitos no bairro $1^{\circ}$ de Maio. c2014. Disponível em: http://www.vilavelha.es.gov.br/noticias/2014/04/videomonitoramento-ajuda-na-prisao-de-suspeitos-no-bairro-1o-de-maio5124. Acesso em: 01 abr. 2015.

WAISELFISZ, Julio Jacobo. Mapa da violência 2015: mortes matadas por arma de fogo. Rio de Janeiro: CEBELA, FLACSO; Brasília: Seppir, 2015. Disponível em: http://www.mapadaviolencia.org.br/mapa2015.php. Acesso em: 14 mar. 2016 .

ZANOTELLI, Cláudio Luiz; MEDINA, Jorge Lellis Bomfim. Análise dos discursos sobre a criminalidade e a delinquência nos jornais A Gazeta, Notícia Agora e A Tribuna e seus efeitos sobre a política de segurança e a percepção social de (in) segurança. 166f. Relatório de pesquisa - Secretaria de Segurança Urbana da Prefeitura Municipal de Vitória, fev. 2008. 
ZANOTELLI et. al. Atlas da criminalidade no Espírito Santo. São Paulo: Annablume, Fapes, 2011. 218p. 